\title{
Effects of chronic cadmium exposures on growth of larvae of an Hawaiian bivalve, Isognomon californicum
}

\author{
Amy Huffman Ringwood \\ Duke University Marine Laboratory, Pivers Island, Beaufort, North Carolina 28516, USA
}

\begin{abstract}
Young bivalve larvae ( $3 \mathrm{~d}$ old) were exposed to environmentally realistic concentrations of cadmium $\left(2,10,20\right.$, and $\left.50 \mu \mathrm{g} \mathrm{l}^{-1}\right)$ under static exposure conditions for $28 \mathrm{~d}$, a period that spans most of their larval lifespan. The effects on growth were evaluated in terms of both size and weight parameters. Cd effects on size growth (length and height) were significantly different, but subtle, mostly characterized by a slow gradual decline, but remaining at $\geq 80 \%$ of control sizes. However the effects of $\mathrm{Cd}$ on weight (total dry weight, shell weight, and tissue weight) were much more dramatic. After only $4 \mathrm{~d}, \mathrm{Cd}$-exposed larvae weighed $<80 \%$ of the controls (total dry weight), and tissue weights were between 35 and $51 \%$ of controls. With continued exposures, there was some improvement, but then growth stabilized at levels significantly lower than the controls or continued to decline. This response of initial severe effects, readjustment, and restabilization represents an adaptive response mediated by homeostatic mechanisms. However, the mechanisms were unable to ameliorate the toxic effects. Therefore, weight was more sensitive than size as an indicator of adaptive response and stress. The capacity for recovery was evaluated by exposing some larvae to $\mathrm{Cd}$ for $14 \mathrm{~d}$ and allowing them to depurate for $14 \mathrm{~d}$. Only larvae initially exposed to $2 \mu \mathrm{g} \mathrm{l} \mathrm{l}^{-1} \mathrm{Cd}$ showed significant recovery. The effects on growth are discussed with regard to $\mathrm{Cd}$ tissue concentrations and regulatory mechanisms.
\end{abstract}

\section{INTRODUCTION}

Elevated metal concentrations are often found in coastal and estuarine ecosystems. Metals tend to be insidious toxins, whose effects are often chronic, rather than acute, so although levels high enough to cause sudden kills of organisms are rarely achieved, chronic long-term effects may be serious. When animals are stressed by altered environmental conditions, homeostasis is disrupted, and animals must adjust, behaviorally or physiologically, to adapt to the surrounding conditions. If the adaptations for re-establishment of homeostasis are insufficient, the organisms will suffer chronic stress or die. Methods to assess for signs of chronic toxicity have included biochemical, cytochemical, histological, and physiological indices (MacInnes \& Thurberg 1973, Moore \& Stebbing 1976, Stromgren 1982, Akberali \& Trueman 1985, Bayne et al. 1985, Bayne et al. 1988).
Ideally, one goal of chronic toxicity studies would be identification of a unique stress response for a specific pollutant or pollutant type, enabling recognition of both when animals are stressed and the cause. For example, 'imposex', the induction of male sex characters in the females of the gastropod Nucella lapillus, has been specifically associated with tributyltin contamination (Bryan et al. 1986). However, for most metals, stress responses of animals are more generalized due to widespread effects on feeding and digestion, respiration, and reproduction (Bayne et al. 1985, Vernberg et al. 1985). Growth is a particularly useful stress index because it is the result of integrated biochemical and physiological responses of an organism to environmental conditions (Widdows 1985). Another goal of chronic toxicity studies is to identify responses that could be used as a signal of adverse environmental conditions before the biota are irreversibly damaged. It is important to use species or life stages and responses that are sufficiently sensitive. 
Although it is generally believed that larvae are more sensitive than adults, there are few studies on the effects of chronic metal exposures in which larvae are exposed to environmentally realistic concentrations (Brereton et al. 1973, Watling 1982).

In the present study, larvae of an Hawaiian bivalve, Isognomon californicum, were exposed to low, environmentally realistic concentrations of cadmium $(2,10,20$, and $50 \mu \mathrm{g} \mathrm{l}^{-1}$ ) for $28 \mathrm{~d}$, and the effects on growth were evaluated on the basis of both size and weight parameters. The capacity to recover from cadmium stress during depuration was also addressed, and the usefulness of the various growth parameters as indicators of stress is discussed. These results are also evaluated with regard to a previous study on the accumulation of cadmium by I. californicum larvae (Ringwood 1989).

\section{MATERIALS AND METHODS}

All experiments were conducted at Pacific Biomedical Research Center, Kewalo Marine Laboratory, University of Hawaii, Honolulu (USA). Isognomon californicum, typical of many bivalve species, broadcast eggs and sperm so fertilization and development occur externally. Their veliger larvae spend an estimated $32 \mathrm{~d}$ in the plankton before they reach the pediveliger stage, the stage at which they descend to the benthos and metamorphose. Therefore the $28 \mathrm{~d}$ exposure period of these experiments spans most of their larval life. Adults of $I$. californicum were readily induced to spawn in the laboratory by lowering the salinity to $16 \%$. Generally 50 or more adults were placed in a spawning dish, as well as eggs and sperm from several adults (typically 5 to 10 or more males and females spawned). Embryos and larvae were reared in filtered seawater $(0.45 \mu \mathrm{m})$ at ambient salinity (34\%) and temperature $\left(24^{\circ} \mathrm{C}\right)$. By $48 \mathrm{~h}$ after fertilization, shelled veliger larvae were fully formed, characterized by a large circular velum used for both swimming and feeding. Cadmium exposures were initiated $3 \mathrm{~d}$ after fertilization, and larvae were exposed to $\mathrm{CdCl}_{2}$ for 28 d. Larvae were exposed to 5 treatments $(0,2,10,20$, and $50 \mu \mathrm{g} \mathrm{l}^{-1} \mathrm{Cd}$ ), in $2 \mathrm{l}$ glass beakers (10 larvae $\mathrm{ml}^{-1}$ ) with 3 replicates for each treatment. The water in the cultures was changed every other day, and cadmium and food (mixture of Isochrysis galbana and Chaetoceros gracilis, $2 \times 10^{4}$ cells $\mathrm{ml}^{-1}$ ) were renewed at that time. Cadmium was added directly to the water, but food phytoplankters certainly accumulated some cadmium prior to being eaten, so although the water was the primary source of cadmium, some cadmium entered via the food. However it has been found in adult bivalves that uptake of cadmium via food is insignificant compared to uptake from water (Borchardt
1983, Riisgard et al. 1987). Also, these concentrations represent maximal concentrations, since some cadmium probably adsorbs to the beakers. However, based on previous experiments (Ringwood 1989), added cadmium was in excess of estimated accumulated cadmium (total cadmium added to each 2 l beaker would range from 4 to $100 \mu \mathrm{g}$ and estimated cadmium removed by the larvae would range from ca 0.01 to $0.25 \mu \mathrm{g} \mathrm{d}^{-1}$ ). Some larvae were exposed to cadmium for the entire $28 \mathrm{~d}$, but after $14 \mathrm{~d}$, each culture was subdivided so that half of the larvae were ongrown in clean seawater for the remaining $14 \mathrm{~d}$. Samples of larvae for growth measurements were taken on Days $4,7,10,14,21$, and 28 of the experiments, and fixed in $10 \%$ formalin in seawater

The effects of cadmium on growth were evaluated on the basis of both size (length and height) and weight (total dry weight, shell weight, tissue weight) criteria. For size measurements, fixed larvae were transferred to a microscope slide, and the images projected from a drawing tube attached to a compound microscope were traced onto paper. Length llongest distance parallel to the hinge) and height (longest distance perpendicular to the hinge) were measured from the tracings with a Hitachi digitizer using Autocad computer graphics program (Fig. 1). Ten larvae were measured from each replicate, so a total of 30 larvae were measured for each treatment/sample day.

For total dry weight measurements, samples of fixed larvae were placed in preweighed foil pans $(20$ to 50 larvae per pan), rinsed with $3 \%$ ammonium formate to remove excess salts, counted, lyophilized, and weighed to the nearest microgram on a Cahn electrobalance. The larvae were then ashed for $3 \mathrm{~h}$ at $500^{\circ} \mathrm{C}$ and reweighed. Ash weight was treated as shell

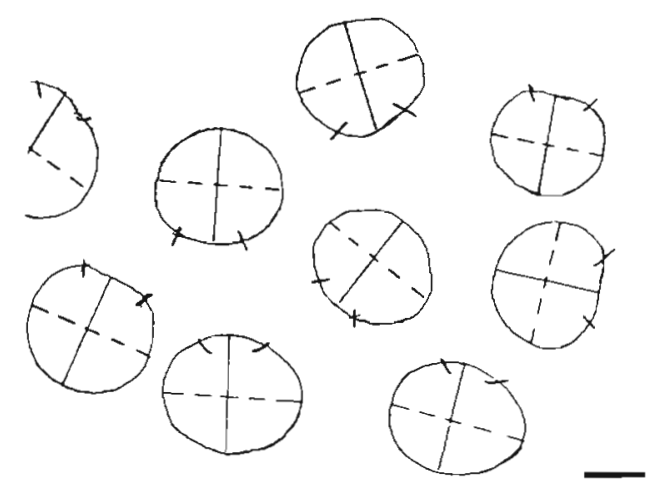

Fig. 1 Isognomon californicum. Tracings of $7 \mathrm{~d}$ old control larvae used for size measurements, illustrating the methods used for measuring length and height. Two marks were made on each tracing to designate the location of the hinge. Length was measured as longest distance parallel to the hinge (dashed lines); height, as the longest distance perpendicular to the hinge (solid lines). Scale bar $=50 \mu \mathrm{m}$ 
weight, and the tissue weight was estimated by subtraction of shell weight from total dry weight (Kempf 1981, Kempf \& Hadfield 1985). Three samples (20 to 50 larvae sample ${ }^{-1}$ ) were taken from each replicate, so for each treatment/sample day, $n=9$, and represented a total of 200 to 500 larvae.

Means and standard deviations of all growth parameters were computed and compared by analysis of variance. An a posteriori analysis (Student-NewmanKeuls) was used to determine which treatments were significantly different from each other. The level of significance was $p \leq 0.05$. Results were expressed as percent of controls for graphical presentations. The data presented in this paper are from 1 of 4 comparable experiments, all of which yielded similar, very repeatable results.

\section{RESULTS}

During the $28 \mathrm{~d}$ experiments, larvae of Isognomon californicum grew rapidly, measuring $85 \mu \mathrm{m}$ in length at the beginning of the experiment and growing to $230 \mu \mathrm{m}$ by the end. There are no data for the $50 \mu \mathrm{g} \mathrm{l}^{-1}$ treatment after $21 \mathrm{~d}$ because larvae exposed to this concentration suffered massive mortalities between Days 22 and 24. This same phenomenon was observed in other experiments with concentrations $\geq 50 \mu \mathrm{g} \mathrm{l}^{-1}$ $\mathrm{Cd}$. No apparent differences in losses of larvae in all other treatments and controls were observed. When bivalve larvae were exposed to cadmium, significant adverse effects on all growth parameters were observed. However there were distinct differences in how size growth and weight growth were affected. After only $4 \mathrm{~d}$ of exposure, significant effects on total dry weight, shell weight, and tissue weight were observed for all cadmium concentrations. Adverse effects on shell size (length and height) were observed after $4 \mathrm{~d}$ only for those larvae exposed to the highest concentration, $50 \mu \mathrm{g} \mathrm{l}^{-1} \mathrm{Cd}$, and significant adverse effects on size growth for the lower exposure concentrations $\left(2,10,20 \mu \mathrm{g} \mathrm{l}^{-1} \mathrm{Cd}\right)$ were observed after 7 to $10 \mathrm{~d}$ of exposure. The lengths of cadmium-exposed larvae did not drop below $85 \%$ of the controls until after $14 \mathrm{~d}$ of exposure (Fig. 2), and those exposed to 2 $\mu \mathrm{g}^{-1} \mathrm{Cd}$ were not significantly different from the controls. After $21 \mathrm{~d}$, only those exposed to $50 \mu \mathrm{g} \mathrm{l}^{-1}$ $\mathrm{Cd}$ were significantly different from the controls, but by $28 \mathrm{~d}$ all treatments were significantly different. The pattern observed for height (not shown in Fig. 2)

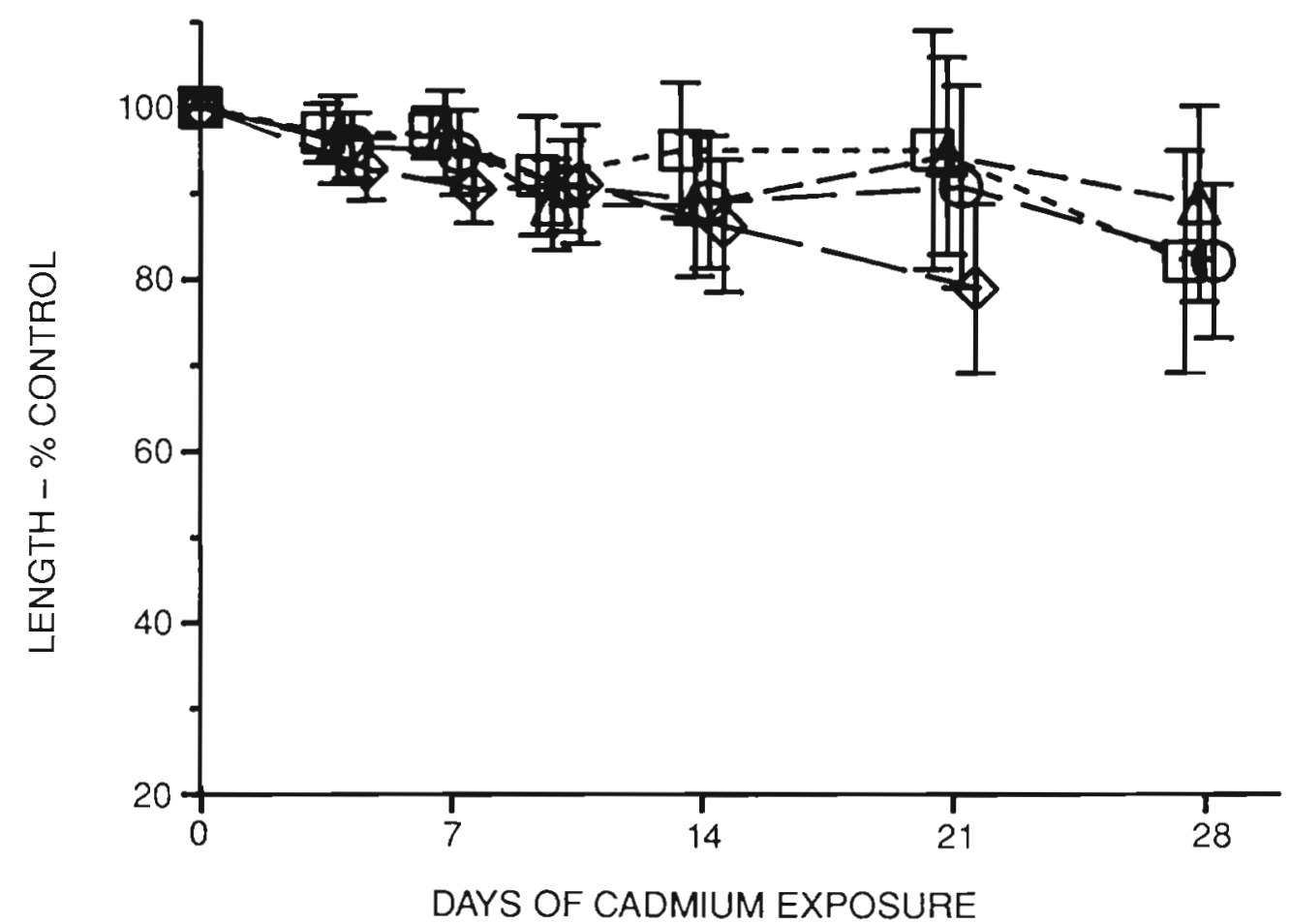

Fig. 2. Isognomon californicum. Effects of cadmium on length growth of larvae. Values are mean $\mu \mathrm{m} \pm \mathrm{SD}$, expressed as percent of controls. $(\square---\square) 2 \mu \mathrm{g} \mathrm{l}^{-1} ;(\Delta---\Delta) 10 \mathrm{~g} \mathrm{I}^{-1} ;(0--\mathrm{O}) 20 \mu \mathrm{g} \mathrm{l}^{-1} ;(\diamond-\longrightarrow \circlearrowright) 50 \mu \mathrm{g} \mathrm{l^{-1 }}$ All Cd-exposed larvae were significantly smaller at Days 10 and 28 . Only larvae exposed to $50 \mu \mathrm{g} \mathrm{l}^{-1}$ were significantly different for all sample days. At Day 14, larvae exposed to 10 and $20 \mu \mathrm{g} \mathrm{l}^{-1}$ were also significantly different, but not those exposed to $2 \mu \mathrm{g} \mathrm{l^{-1 }}$. At Days 4,7 , and 21 , the 2,10 , and $20 \mu \mathrm{g} \mathrm{l}^{-1}$ treatments caused no significantly different responses 


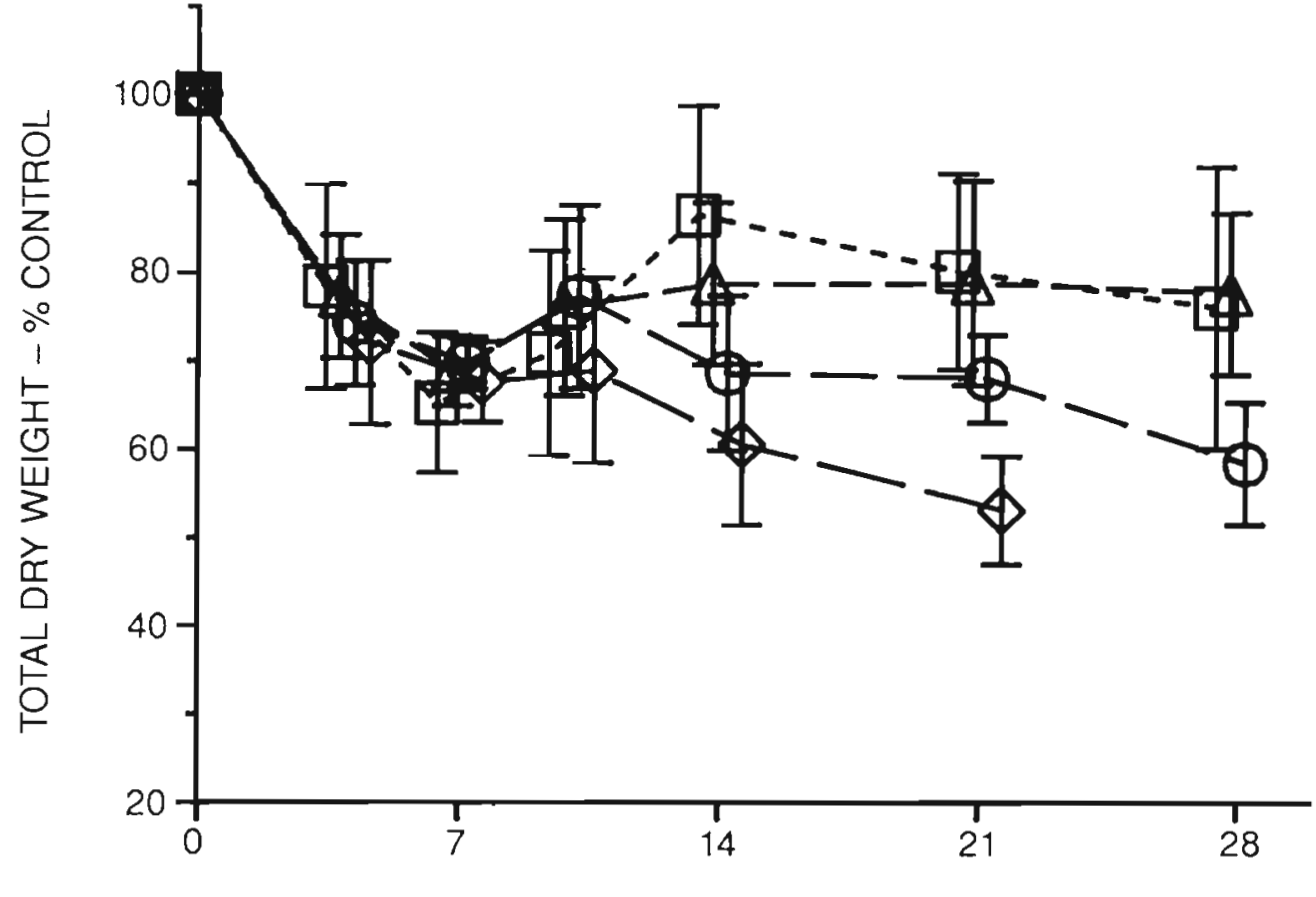

Fig. 3. Isognomon californicum. Effects of cadmium on total dry weight of larvae. Values are mean $\mu \mathrm{g}$ larva ${ }^{-1} \pm \mathrm{SD}$. expressed as percent of controls. Symbols are the same as in Fig. 2. All data are significantly different from controls

DAYS OF CADM!UM EXPOSURE

was the same so there were no allometric effects. However, the effects of cadmium on weight were more dramatic. After only $4 \mathrm{~d}$ of cadmium exposure, the total dry weights of Cd-exposed larvae were already less than $80 \%$ of the controls (Fig. 3)i and after $7 \mathrm{~d}$, dry weights of Cd-exposed larvae were less than $70 \%$ of the controls. The effects of cadmium on the components of weight, shell weight and tissue weight. are shown in Fig. 4. Effects of $\mathrm{Cd}$ on tissue weights were especially severe, with tissue weights of $\mathrm{Cd}$ exposed larvae ranging between 35 and $51 \%$ of the controls after only $4 \mathrm{~d}$ (Fig. $4 \mathrm{~B}$ ) With continued exposure, there was some improvement in the weights of $\mathrm{Cd}$-exposed larvae relative to control larvae (although only the tissue weights of larvae exposed to $2 \mu \mathrm{g} \mathrm{I}^{-1}$ $\mathrm{Cd}$ for $14 \mathrm{~d}$ were not significantly different from controls), but then growth stabilized at levels significantly lower than the controls, or declined for the remainder of the experiments.

For larvae exposed to cadmium for $14 \mathrm{~d}$ and ongrown in clean seawater for $14 \mathrm{~d}$, recovery from adverse effects was observed only in those initially exposed to $2 \mu \mathrm{g} \mathrm{l}^{-1} \mathrm{Cd}$ (Table 1). No larvae survived exposure to $50 \mathrm{\mu g} \mathrm{l}^{-1}$. Generally, there was a trend of improved growth during the depuration period in all other Cd-exposed larvae. Sizes and weights of ongrown larvae initially exposed to 10 and $20 \mu \mathrm{g} \mathrm{l}^{-1}$ were not significantly different from those that were continuously exposed, all significantly lower than controls.

\section{DISCUSSION}

During 28 d exposures to cadmium, growth of Isognomon californicum larvae was significantly lower than that of control larvae. In the open ocean or in nonpolluted seawater, cadmium concentrations are $\leq 0.1 \mu \mathrm{g} \mathrm{l}^{-1}$, but in polluted estuaries, values as high as $50 \mu \mathrm{g} \mathrm{l}^{-1}$ have been reported (Holmes et al. 1974 . Coombs 1979, Fasset 1980). Therefore, the concentrations used in these experiments ( 2 to $50 \mu \mathrm{g} \mathrm{l}^{-1} \mathrm{Cd}$ ) are environmentally realistic. The results indicate that even moderately elevated concentrations of cadmium. in coastal environments could adversely affect larval growth. Moreover, weight was a more sensitive indicator of toxicity than size. Most previous studies on the effects of metals on growth have evaluated the effects on size (Calabrese et al. 1977. Beaumont et al. 1987). Watling (1982) exposed oyster larvae to 10, 20,50, and $100 \mu \mathrm{g} \mathrm{l}^{-1} \mathrm{Cd}$ for $4 \mathrm{~d}$, and observed significant effects on length growth only in those larvae exposed to 50 and $100 \mu \mathrm{g} \mathrm{l}^{-1} \mathrm{Cd}$. Similarly, in this study, significant depression of size growth of $I$. californicum larvae was observed after $4 \mathrm{~d}$ of exposure only with $50 \mathrm{\mu g} \mathrm{l}^{-1} \mathrm{Cd}$. However, all concentrations tested in these studies significantly affected total dry weight, tissue dry weight, and shell dry weight after only $4 \mathrm{~d}$.

When animals encounter changing environmental conditions, they respond in an adaptive manner The immediate response involves behavioral and/or physiological changes, and is often characterized by 


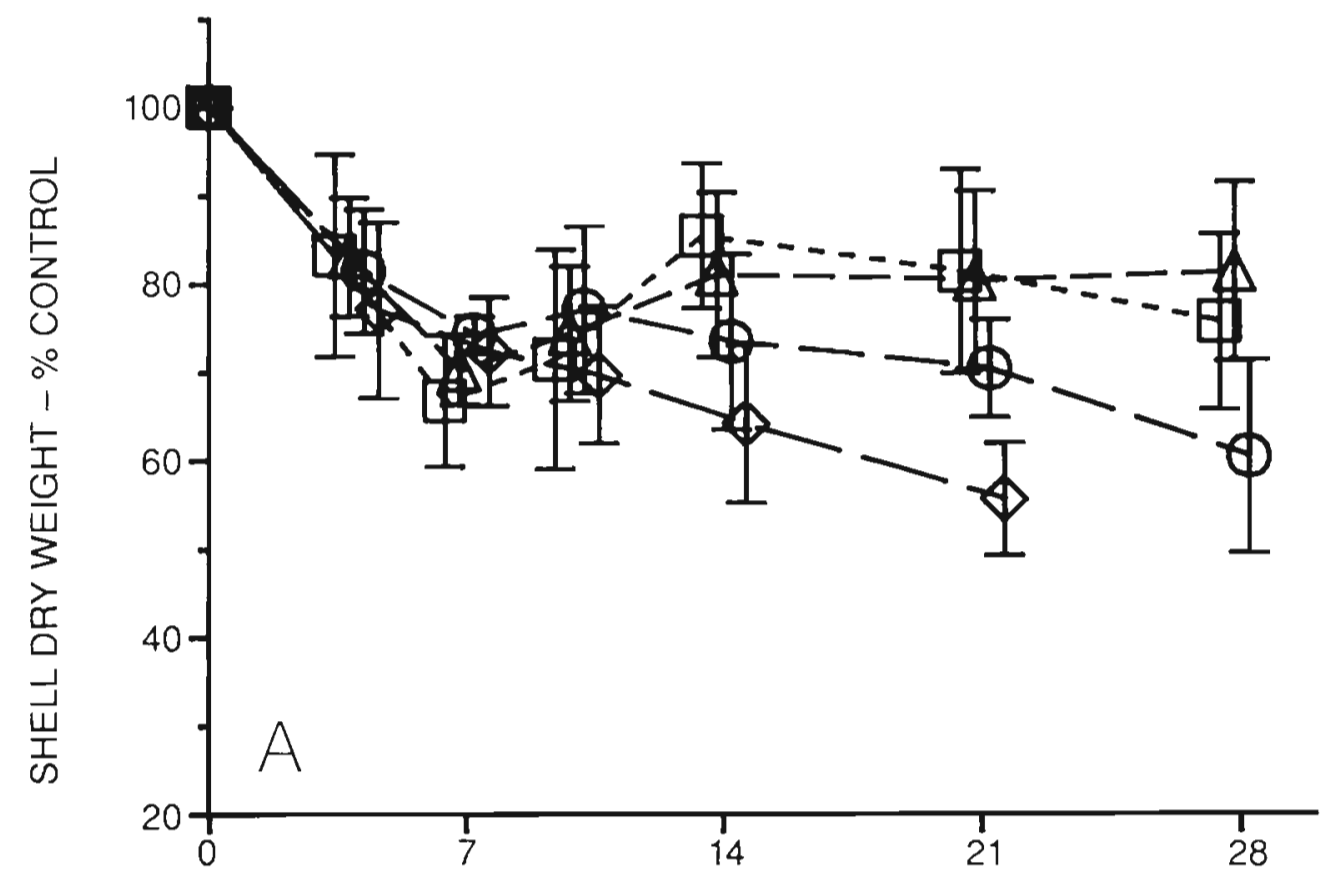

DAYS OF CADMIUM EXPOSURE

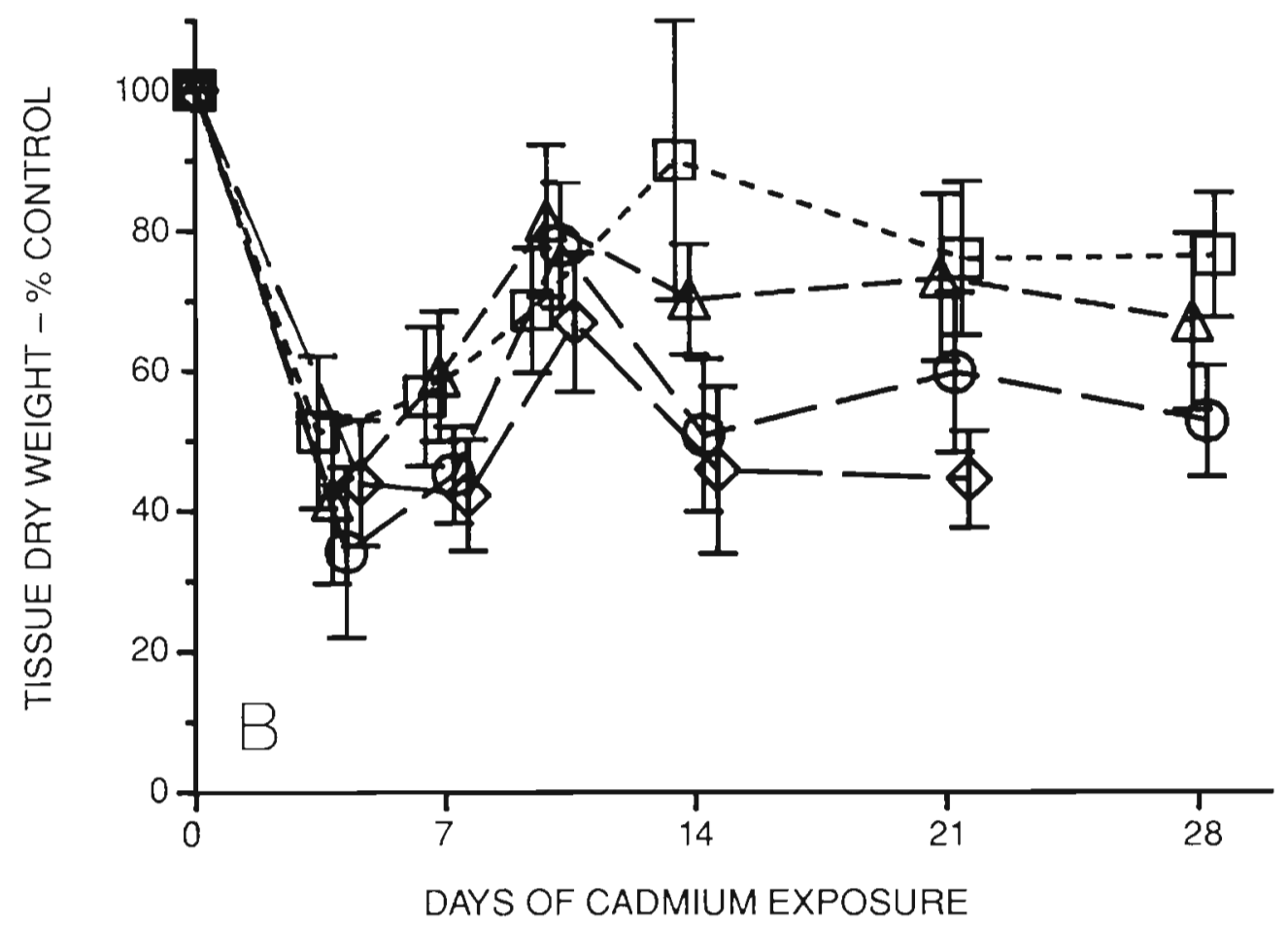

Fig. 4. Isognomon californicum. Effects of cadmium on (A) shell dry weight, and (B) tissue dry weight of larvae. Values are mean $\mu \mathrm{g}$ larva $\mathrm{a}^{-1} \pm \mathrm{SD}$, expressed as percent of controls. Symbols are the same as in Fig. 2. All shell dry weight values are significantly different from controls. All tissue dry weight values are also significantly different from controls, except the data point for larvae exposed to $2 \mathrm{\mu g} \mathrm{l}^{-1} \mathrm{Cd}$ at Day 14

'over-shoot' or 'undershoot' phenomena, in which a response such as respiration or growth is dramatically stimulated or depressed. The immediate re- sponse is followed by a period of readjustment, and finally establishment of a new steady state. If the new steady state is not significantly different from 
Table 1. Isognomon californicum. Weights and sizes of larvae exposed to cadmium for $28 \mathrm{~d}$ (continuously exposed), or exposed to cadmium for $14 \mathrm{~d}$ followed by $1.4 \mathrm{~d}$ in clean seawater (ongrown). Values for Day 28 of the experiments are reported as mean $\pm \mathrm{SD}_{i}$ length and height are reported as $\mu \mathrm{m} \mathrm{larva}^{-1}$, weights as $\mu \mathrm{g} \mathrm{larva}^{-1}$

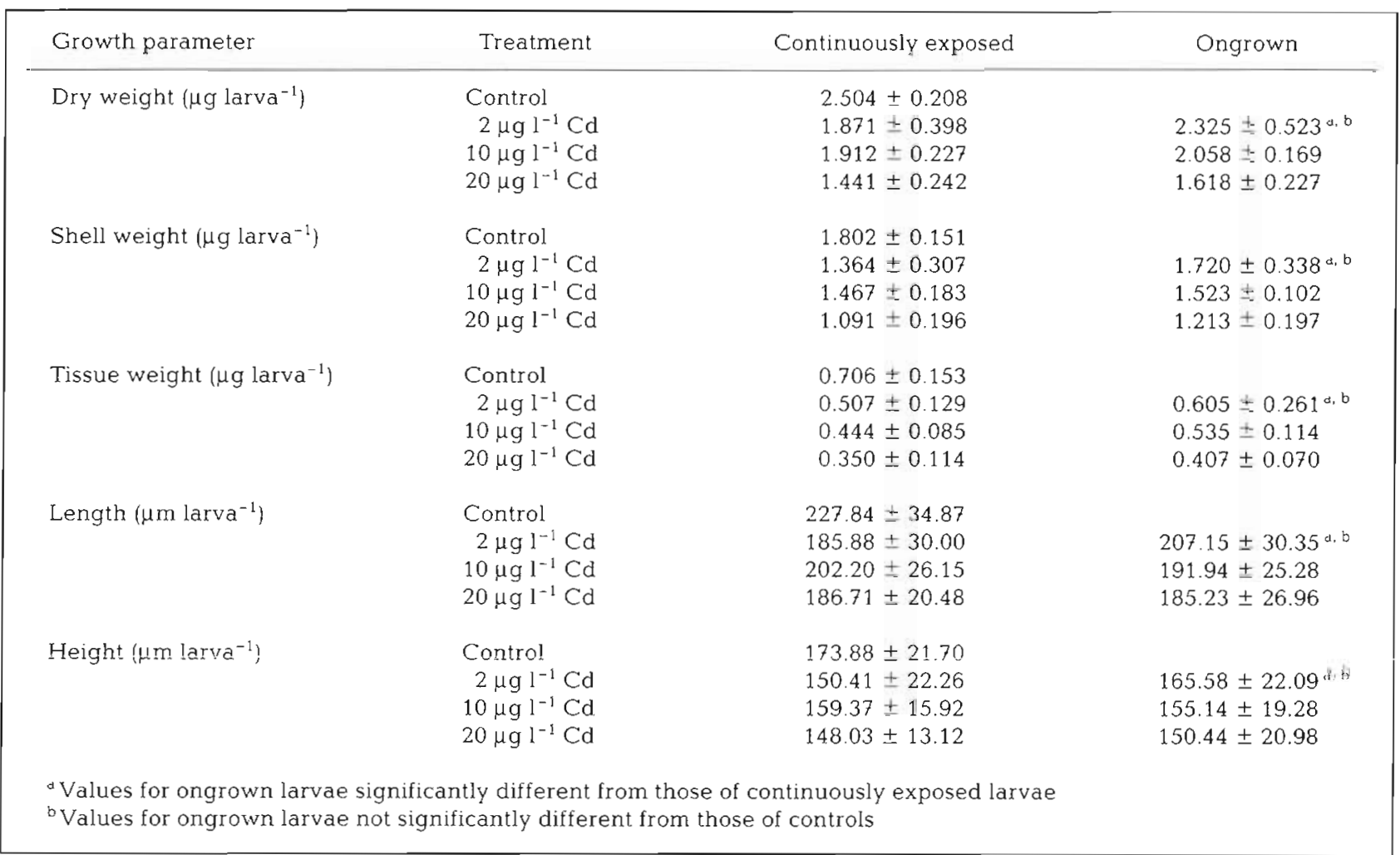

the initial level, then the animals have successfully acclimated or adapted. If however, the new steady state level is lower or decline continues, then those animals are said to be stressed (Kinne 1964, Bayne et al. 1985). This pattern of homeostatic response could be used to describe the effects of cadmium on weight growth of Isognomon californicum larvae. Initially, during the first 4 to $7 \mathrm{~d}$ of cadmium exposure, growth rates were severely depressed, especially with regard to tissue weight. During the readjustment phase, partial recovery was observed. However, with continued exposure, complete homeostatic adjustment was not achieved, resulting in a stressed condition.

The partial recovery during the readjustment phase would be mediated by detoxification mechanisms that sequestered cadmium and prevented interaction with essential cell processes. Cadmium sequestering mechanisms have been studied extensively in adult bivalves, and metallothioneins (MT), a class of metal binding proteins believed to be important in cadmium detoxification in vertebrate as well as invertebrate species, have been isolated (Engel \& Brouwer 1984, Hamer 1986, Roesijadi et al. 1989). The existence of MTs or other detoxification systems in larval bivalves has not been studied. It has been reported that induction of MT in adult oysters was not observed until $4 \mathrm{~d}$ of exposure to $50 \mu \mathrm{g} \mathrm{l}^{-1} \mathrm{Cd}$ (Roesijadi \& Klerks 1989). It is interesting to note recovery associated with the readjustment phase in larvae of Isognomon californicum was observed after $4 \mathrm{~d}$ of exposure. The results of this study suggest that some type(s) of cadmium detoxification or sequestration mechanisms occur in larval bivalves, and that they become effective 4 to 7 d after cadmium exposures.

At first, during initial exposure periods, the severe Cd effects on weight did not manifest themselves in a significant dose-related manner". Only after $14 \mathrm{~d}$ of exposure do larval weights of different exposure concentrations vary in a dose-related manner. This is particularly surprising since it was shown in a previous study that larval tissue accumulation rates are dose dependent: $6.7 \mu \mathrm{g} \mathrm{g}^{-1}$ dry weight $\mathrm{d}^{-1}$ for larvae exposed to $2 \mu \mathrm{g} \mathrm{I}^{-1} \mathrm{Cd}$, and $50 \mu \mathrm{g} \mathrm{g}^{-1}$ dry weight $\mathrm{d}^{-1}$ for

\footnotetext{
- In other experiments, Iarvae exposed to lower Cd concentrations $\left(0.1,0.2,0.5,1 \mu \mathrm{g} \mathrm{l^{-1 }} C d\right)$ for $4 \mathrm{~d}$ suffered the initial severe effects on weight growth with all but $0.1 \mu \mathrm{g} \mathrm{I}^{-1} \mathrm{Cd}$. For all other concentrations, Cd-exposed larvae weighed $<68 \%$ of controls
} 
Table 2. Isognomon californicum. Cadmium concentrations of larval tissues during $28 \mathrm{~d}$ exposures to 2 and $20 \mathrm{\mu g} \mathrm{l}^{-1} \mathrm{Cd}$

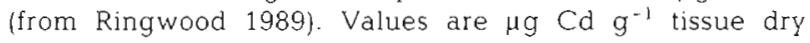
weight, mean $\pm \mathrm{SD}$

\begin{tabular}{|c|c|c|}
\hline \multirow{2}{*}{$\begin{array}{l}\text { Days of cadmium } \\
\text { exposure }\end{array}$} & \multicolumn{2}{|c|}{ Exposure concentrations } \\
\hline & $2 \mu \mathrm{gl}^{-1} \mathrm{Cd}$ & $20 \mu \mathrm{gl} \mathrm{l}^{-1} \mathrm{Cd}$ \\
\hline 4 & $19.6 \pm 3.6$ & $221.3 \pm 29.8$ \\
\hline 7 & $28.1 \pm 7.6$ & $224.5 \pm 47.0$ \\
\hline 10 & $58.9 \pm 11.0$ & $401.9 \pm 29.4$ \\
\hline 14 & $65.6 \pm 8.4$ & $599.2 \pm 92.7$ \\
\hline 21 & $101.6 \pm 11.1$ & $761.2 \pm 71.1$ \\
\hline 28 & $98.2 \pm 4.8$ & $1041.4 \pm 74.3$ \\
\hline
\end{tabular}

larvae exposed to $20 \mu \mathrm{g} \mathrm{I}^{-1} \mathrm{Cd}$ (Ringwood 1989). The tissue concentrations of cadmium in larvae exposed to these 2 concentrations are listed in Table 2. These data (taken from Ringwood 1989) suggest that prior to activation of detoxification mechanisms, accumulation of as little as $20 \mu \mathrm{g} \mathrm{g}^{-1}$ causes adverse effects, as severe as those caused by much higher concentrations. However once activated, larvae could contain tissue concentrations of approximately $65 \mathrm{\mu g} \mathrm{g}^{-1}$ (larvae exposed to $2 \mu \mathrm{g} \mathrm{l}^{-1} \mathrm{Cd}$ for $14 \mathrm{~d}$ ) and not be significantly different from controls.

Larvae exposed to cadmium for $14 \mathrm{~d}$ and ongrown in clean seawater for $14 \mathrm{~d}$ continued to be stressed in most cases. Only larvae initially exposed to $2 \mu \mathrm{g} \mathrm{l}^{-1} \mathrm{Cd}$ showed significant improvement in growth. The ability to recover may be related to the magnitude of the effects on tissue weight during the first phase of exposure. During the first $4 \mathrm{~d}$ of cadmium exposure, mean tissue weight of larvae exposed to $2 \mu \mathrm{gl}^{-1} \mathrm{Cd}$ was $51 \%$ of the control weight. Tissue weights of larvae, relative to controls, exposed to 10,20 , and $50 \mu \mathrm{g} \mathrm{l}^{-1} \mathrm{Cd}$ were 42,34 and $44 \%$, respectively. Therefore, in this study, when tissue weights of cadmium-exposed larvae were depressed by more than $50 \%$, they were unable to recover even when cadmium was removed. Mechanistically, it could be hypothesized that recovery or failure to recover during depuration could be related to differential loss rates. During the $14 \mathrm{~d}$ depuration period, Cd loss by larvae exposed to 2 and $20 \mu \mathrm{g} \mathrm{l}^{-1} \mathrm{Cd}$ was rapid, so the failure to recover cannot be readily explained by this hypothesis (Ringwood 1989). Tissue concentrations in larvae at the end of the depuration period were $20.2 \pm 8.2 \mu \mathrm{g} \mathrm{g} \mathrm{g}^{-1}$ for larvae exposed to $2 \mu \mathrm{g} \mathrm{l}^{-1} \mathrm{Cd}$, and $106.4 \pm 12.5 \mu \mathrm{g} \mathrm{g}^{-1}$ for those exposed

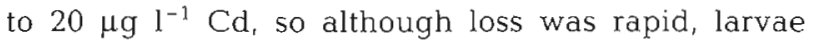
exposed to $20 \mathrm{\mu g} \mathrm{l}^{-1}$ still contained a substantial amount of cadmium. Another plausible hypothesis is that if body concentrations exceed the capabilities of the detoxification system(s), irreversible damage occurs. From Table 2, one is tempted to speculate that ca $100 \mu \mathrm{g} \mathrm{g}^{-1}$ tissue dry weight may be the critical concentration. Larvae exposed to $2 \mu \mathrm{g} \mathrm{l^{-1 }} \mathrm{Cd}$ were not significantly different from controls after $14 \mathrm{~d}$ of exposure, but by 21 d they were significantly different. Larvae removed from cadmium prior to reaching $100 \mu \mathrm{g} \mathrm{Cd} \mathrm{g}^{-1}$ tissue dry weight and allowed to depurate were able to recover The scenario could thus be envisioned as follows. Bivalve larvae exposed to very low environmentally feasible concentrations of cadmium will initially suffer severe adverse effects. Activation of detoxification mechanisms would result in the effective isolation of cadmium, reducing its interaction with cellular processes. However, as exposure continues and the body concentration exceeds the limits of the detoxification system (possibly in the range of $100 \mathrm{\mu g} \mathrm{g}^{-1}$ ), irreversible damage occurs. If cadmium is removed from the environment prior to exceeding the detoxification systems' limits, recovery can occur.

In conclusion, bivalve larvae were adversely affected by chronic environmentally realistic concentrations of cadmium (ranging from 2 to $50 \mu \mathrm{g}^{-1}$ ). Weight was more sensitive than size as an indicator of adaptive response and stress. It is not known if the patterns observed in this study are metal specific or species specific, but it is more probable that this represents a generalized stress response. Combining the results of this toxicity study with those from previous studies on bioaccumulation, the significance of body concentrations to toxicity and recovery suggests that the developmental stages of bivalves may be valuable tools for identifying the potential for chronic toxicity and improving our understanding of the roles of regulatory mechanisms in amelioration of toxicity.

Acknowledgements. I thank Dr Michael G. Hadfield and Dr Sidney J. Townsley for guidance in this research.

\section{LITERATURE CITED}

Akberali, H. B., Trueman, E. R. (1985). Effects of environmental stress on marine bivalve molluscs. Adv. mar Biol. 22 $101-198$

Bayne, B. L., Brown, D. A., Burns, K., Dixon, D. R., Ivanovici, A. M., Livingstone, D. R., Lowe, D. M., Moore, M. N., Stebbing, A. R. D., Widdows, J. \{1985\}. The effects of stress and pollution on marine animals. Praeger Scientific, New York

Bayne, B. L., Clarke, K. R., Gray, J. S. (eds.) (1988). Biological effects of pollutants. Mar. Ecol. Prog. Ser. 46: 1-278

Beaumont, A. R., Tserpes, G., Budd, M. D. (1987). Some effects of copper on the veliger larvae of the mussel Mytilus edulis and the scallop Pecten maximus (Mollusca, Bivalvia). Mar. environ. Res. 21: 299-309

Borchardt, T. (1983). Influence of food quantity on the kinetics of cadmium uptake and loss via food and seawater in Mytilus edulis. Mar. Biol. 76: 67-76 
Brereton, A., Lord, H., Thornton, I., Webb, J. S. (1973). Effect of zinc on growth and development of larvae of the Pacific oyster Crassostrea gigas. Mar. Biol. 19: 96-101

Bryan, G. W., Gibbs, P. E., Hummerstone, L. G., Burt, B. R (1986). The decline of the gastropod Nucella lapillus around south-west England: evidence for the effect of tributyltin from antifouling paints. J. max. biol. Ass. U.K. 66: 611-640

Calabrese, A., Macinnes, J. R., Nelson, D. A., Miller, J E. (1977). Survival and growth of hivalve larvae under heavy-metal stress. Mar. Biol. 41: 179-184

Coombs, T A. (1979). Cadmium in aquatic organisms. In: Webb, M. (ed.) The chemistry, biochemistry, and biology of cadmium. Elsevier, North-Holland, p. 93-140

Engel, D., Brouwer, M. (1984). Trace metal-binding proteins in marine molluscs and crustaceans. Mar. environ. Res. 13: $177-194$

Fasset, D. W. (1980). Cadmium. In: Waldron, H. A. led.) Metals in the environment. Academic Press, London, p. $61-110$

Hamer, D. H. (1986). Metallothionein. A. Rev. Biochem. 55 913-951

Holmes, C. W., Slade, E. A., McLerran, C. J. (1974). Migration and redistribution of zinc and cadmium in marine estuarine systems. Environ. Sci. Techol. 8: 255-259

Kempf, S. C. (1981). Long-lived larvae of the gastropod Aplysia juliana: do they disperse and metamorphose or just slowly fade away? Mar. Ecol. Prog. Ser. 6: 61-65

Kempf, S. C., Hadfield, M. G. (1985). Planktotrophy by the lecithotrophic larvae of a nudibranch, Phestillia sibogae (Gastropoda). Biol. Bull. 169: 119-130

Kinne, O. (1964). The effects of temperature and salinity on marine and brackish-water animals. I. Temperature Oceanogr. mar. Biol. A. Rev. 1: 301-340

This article was submitted to the editor
Maclnnes, J. R., Thurberg, F. P. (1973). Effects of metals on the behaviour and oxygen consumption of the mud snail. Mar. Pollut. Bull. 4: 185-186

Moore, M. N., Stebbing, A. R. D. (1976). The quantitative cytochemical effects of three metal ions on a lysosomal hydrolase of a hydrojd. J. mar. biol. Ass. U.K. 56: 995-1005

Riisgard, H. U., Bjornestad, E., Mohlenberg, F. (1987). Accumulation of cadmium in the mussel Mytılus edulis: kinetics and importance of uptake via food and water. Mar. Biol. 96: 349-353

Ringwood, A. H. (1989). Accumulation of cadmium by larvae and adults of an Hawaiian bivalve, Isognomon californicum, during chronic exposure. Mar. Biol. 102: 499-504

Roesijadi, G., Klerks, P. L. (1989). Kinetic analysis of cadmium binding to metallothionein and other intracellular ligands in oyster gills. J. exp. Zool. 251: 1-12

Roesijadi, G., Kielland, S., Klerks, P. (1989). Purification and properties of novel molluscan metallothioneins. Archs. Biochem. Biophy. 273: 403-413

Stromgren, T. (1982). Effect of heavy metals ( $\mathrm{Zn}, \mathrm{Hg}, \mathrm{Cu}, \mathrm{Cd}$, $\mathrm{Pb}, \mathrm{Ni}$ ) on the length growth of Mytilus edulis. Mar. Biol. 72: $69-72$

Vernberg, F. J., Thurberg, F. P., Calabrese, A., Vernberg, W. B. (eds.) (1985). Marine pollution and physiology: recent advances. Univ. S. Carolina Press, Columbia

Watling, H. R. (1982). Comparative study of the effects of zinc, cadmium, and copper on the larval growth of three oyster species. Bull. environ. Contam. Toxic. 28: 195-201

Widdows, J. (1985). Physiological measurements. In: Bayne, B. L. et al. (eds.) Effects of stress and pollution on marine animals. Praeger, New York, p. 3-45

Manuscript first received: November 27, 1991

Revised version accepted: April 7, 1992 